\title{
A TYPOLOGICAL AND FUNCTIONAL ANALYSIS OF BONE TOOLS FROM CHALCOLITHIC GULPINAR IN NW ANATOLIA
}

\section{KUZEYBATI ANADOLU'DA KALKOLITIK GÜLPINAR YERLEŞiMI BULUNTUSU KEMIK ALETLERIN TIPPOLOJIK VE IŞLEVSEL BİR ANALIZi}

\author{
Makale Bilgisi Article Info \\ Başvuru: 15 Ocak 2021 \\ Received: January 15, 2021 \\ Hakem Değerlendirmesi: 09 Mart 2021 \\ Peer Review: March 09, 2021 \\ Kabul: 20 Nisan 2021 \\ Accepted: April 20, 2021
}

DOI : $10.22520 /$ tubaar2021.28.002

\section{Çilem YAVŞAN*}

\begin{abstract}
This work offers a general overview of bone tools recovered from the Chalcolithic phases at the northwestern Anatolian site of Gülpınar in terms of typology and function. A total of 263 bone tools were retrieved from phase II representing the early Chalcolithic 2 period and the succeeding phase III, belonging to the Middle Chalcolithic period at the site. These specimens all found at domestic contexts help us to establish a typology and allow an assessment regarding the pattern of bone tool use at the site. Bone tools are viewed as utilitarian objects of archaeological significance in elucidating aspects of household life and domestic production activity. Results of the analysis show that tools fashioned from discarded animal bones may have been used in domestic crafts such as coiled basketry, mat making, pot manufacturing, and hide processing. In the light of the minimal number of studies on this category of tools in Chalcolithic western Anatolian archaeology, this study is hoped to contribute to future studies on the typology and function of bone tools.
\end{abstract}

Keywords: Gülpınar, Chalcolithic, Bone Tools, Typology, Function, Domestic Production.

\footnotetext{
Dr., Çanakkale Onsekiz Mart Üniversitesi, Uygulamalı Bilimler Fakültesi, Müzecilik ve Kültürel Miras Yön. Böl. 17100 Çanakkale/Türkiye e-posta: cilemyavsan@comu.edu.tr 


\section{ÖZET}

Bu çalışma kuzeybatı Anadolu'da Gülpınar yerleşiminde Kalkolitik dönemi temsil eden II. ve III. evrelerde ele geçmiş kemik aletleri tipoloji ve işlev açılarından irdeler. Gülpınar'da Erken Kalkolitik 2 dönemi temsil eden Evre II ile Orta Kalkoltik döneme ait Evre III kazıları sırasında toplam 263 kemik alet ortaya çıkarılmıştır. Bu örnekler yerleşim özelinde bir kemik alet tipolojisi oluşturmaya ve yerleşimde kemik alet kullanımı konusunda değerlendirmeler yapmaya olanak sağlar. Kemik aletler hane yaşamı ve yerel üretim faaliyetlerini anlama konusunda önemli sayılan arkeolojik veri kategorilerinden birini oluşturur. Bu çalışmanın sonuçları besin olarak tüketilen hayvanların geriye kalan kemiklerinden şekillendirilen aletlerin hasır veya sepet üretimi yanında çanak çömlek üretimi ile hayvan derilerini işleme gibi genelde hane ölçeğinde yerel üretim faaliyeterinde kullanılmış olabileceğini gösterir. Kalkolitik döneme ait kemik aletler ile ilgili Batı Anadolu arkeolojisinde yapılan çalışmaların az olduğu göz önüne alındığında bu çalışma ileride kemik aletlerin tipolojisi ve işlevi üzerine yapılacak çalışmalara katkı sağlayabilir.

Anahtar Kelimeler: Gülpınar, Kalkolitik, Kemik Aletler, Tipoloji, Işlev, Hane Üretimi. 


\section{INTRODUCTION}

Tools made from animal bones, as well as horns and antlers, clearly formed an important part of household life and domestic production activities in prehistoric times. Although the study of worked bones from archaeological excavations was a relatively neglected field in the past in western Anatolian archaeology, there is now a growing emphasis on the typological, technological, and functional aspects of bone tools in the literature. Several recent comprehensive studies conducted on utilitarian worked bone assemblages from such excavated sites as Karain, Suluin, and Öküzini caves in south-western Anatolia, Ulucak Höyük in central-western Anatolia, Barçın Höyük in inner northwest Anatolia, Aşağı Pınar in Turkish Thrace, and Uğurlu on the island of Gökçeada (Imbros) have already contributed much to our general knowledge of this category of archaeological tools. ${ }^{1}$ Most of these studies took various typological, technological, and functional approaches to the bone tools that were reported from Neolithic contexts. Nevertheless, our archaeological knowledge of the bone tools among the Chalcolithic societies of western Anatolia was quite limited until the rise of new excavations representing this period during the last decade or so. Although recent excavations conducted at such sites as Liman Tepe, Çine Tepecik, Ulucak, Ege Gübre, Yeşilova, Yeşilova/Yassitepe, and Kulaksızlar, as well as Uğurlu on Gökçeada (Imbros) have begun to reveal valuable information regarding most aspects of Chalcolithic life, ${ }^{2}$ unfortunately only several of these sites provided us with finds attesting to the household use of bone tools.

The study of bone tool assemblage from Gülpınar, which is the point of focus of this paper, represents an attempt to contribute to these valuable studies investigating the role of bone tools among Chalcolithic societies of western Anatolia. ${ }^{3}$ The main goal of this work in this sense is firstly to describe and define the types of bone tools excavated within two successive Chalcolithic phases at Gülpınar to form a basic typology based on their working edges. The subsidiary aim is to demonstrate how bone tools might have been used at the site in everyday tasks and household craft production through replication and ethnographic studies, as well as microscopic examination of their used surfaces. Although the precise use of certain bone tool types is unknown, this work relies to a great extent on correlations between the archaeological finds and the information gathered from replication studies and ethnography in formulating a hypothesis on their functions.

\footnotetext{
(e.g.) Bulut 2014; 2016; 2018; Sivil 2017; Dekker 2014; Erdalkıran 2017; Azeri 2015; Paul and Erdoğu 2017.

2 Sağlamtimur and Ozan 2012; Caymaz 2013; Çevik 2018; Erdoğu 2018; Derin and Caymaz 2018; Günel 2018; Takaoğlu and Özdemir 2018; Tuncel and Şahoğlu 2018; Takaoğlu (n.d.); Derin et al. 2020.

3 Yavşan 2020.
}

\section{THE SITE}

Archaeological excavations conducted at the Greek and Roman site of Smintheion (Sanctuary of Apollo Smintheus), located on the southwestern corner of the ancient Troad in northwest Anatolia, brought to light a prehistoric settlement that has multiple phases ranging from the Neolithic to the end of the Chalcolithic period. The site is situated on the outskirts of the modern village of Gülpınar, which gave its name to the prehistoric settlement to separate it from the name given to the sanctuary at later dates. Because the prehistoric site of Gülpınar is a flat extended settlement covering all the sanctuary and beyond, archaeological excavations were confined to only the expropriated areas where the Chalcolithic phases of occupation are well represented. As far as the areas excavated are concerned, the earliest habitation is dated to the Neolithic period, which is labeled as phase I at the site's stratification. No radiocarbon date exists from the Neolithic stratum, which yielded pottery remains closely recalling the assemblages from Ulucak V-IV, Yeşilova IV, and Uğurlu V-IV. After an interval, this was followed by an Early Chalcolithic 2 settlement (phase II) dating between 5320 and 4900/4800 BC. The subsequent Middle Chalcolithic settlement (phase III), witnessings a modification in architectural layout, is dated between $4900 / 4800$ and $4450 / 4300 \mathrm{BC}$ based on radiocarbon dating. ${ }^{4}$ Gülpınar emerges as a rare site where a continuous millennium-long occupation can be observed from ca. $5300 \mathrm{BC}$ to $4300 \mathrm{BC}$, enhancing our archaeological knowledge of Chalcolithic western Anatolia. The phase IV settlement representing the Late Chalcolithic period has not yet been fully excavated due to problems derived from the expropriation of the land. All of these three Chalcolithic strata at Gülpınar were mainly superimposed by Roman, as well as Early and Middle Byzantine occupational layers all around the sanctuary, while the preceding Archaic, Classical, and Hellenistic strata top the prehistoric phases only in certain areas close to the core of the sanctuary, which is the Temple of Apollo Smintheus first built in the second century BC.

Archaeological evidence regarding the subsistence pursuits prevailing at the site has been established through the analyses of animal and plant remains. Animal husbandry based on cattle and sheep/goats and hunting wild animals such as fallow, red, and roe deer as well as wild species of goat, sheep, and boar were predominant activities pursued by the residents of the site during both phases. ${ }^{5}$ The residents of Gülpınar also supplemented their diets with marine sources such as fish, oysters, and mussels, which they caught and gathered from the shallow bays located on the nearby Aegean coast to the west of the site. Moreover, archaeological studies conducted

\footnotetext{
Takaoğlu and Özdemir 2018.

5 Pişkin and Takaoğlu 2020.
} 
on worked organic remains such as animal bones and marine mollusks leftover from meals also demonstrated that a form of small-scale domestic production also took place at the site. For instance, marine mollusks were often used to manufacture tools used in scrapping and abrasion actions, as well as personal ornaments such as beads and pendants. The refuse bones remained from the consumption of animals, on the other hand, were used to produce basic tools that could be used in everyday life, including pot making, weaving, mat making, and hide working ${ }^{6}$.

Archaeological excavations also revealed significant evidence regarding the preparation of food that took place within the courtyards around the dwellings in the settlement. ${ }^{7}$ This includes architectural features related to storage (grain pits, small storage rooms with large pottery containers, silo bases), food processing installations (hearths, ovens, platforms for grinding grain into flour), and waste areas (shell middens, rubbish pits). The finds from the excavated areas at Gülpinar help us to envision several aspects of household life in a typical Chalcolithic western Anatolian settlement. Bone tools played a variety of roles within this system.

\section{METHODOLOGY}

Archaeological excavations conducted at Gülpınar between 2004 and 2013 yielded a relatively small assemblage of bone tools, consisting of 263 specimens. Nearly a dozen bone fragments bearing cut marks have also been recorded among the animal bone assemblage, which overall total 5030 specimens at Gülpınar. ${ }^{8}$ The pieces with various cut marks are excluded from this study as they are not considered to be related to the work of the bone toolmakers. Those pieces that are too fragmented to classify are also excluded from this number of bone tools. During excavations at prehistoric Gülpınar, the tools made from bones as well as horns and antlers recovered from excavated trenches were first recorded in terms of their contextual information. Then, the tool was placed within a group based on its working edge. Because there is no commonly accepted classificatory scheme for the typology of bone tools, our recording strategy of bone tools emulated the excavation conducted at Sitagroi in northern Greece. ${ }^{9}$ As a result, the bone tools from Gülpınar were placed in categories such as 'bevel ended', 'point ended', 'round ended', 'spatulae', and 'hafts'. This was followed by the description, measurement, and taxonomy. The description stage placed particular emphasis on the recording of micro traces such as vertical or horizontal striations and polishes. This was achieved using a Trinocular Zoom Stereo Microscope with

\footnotetext{
Yavşan 2010 and 2020.

Özdemir 2017.

Pişkin and Takaoğlu 2020.

9 Elster 2003.
}

integrated LED illumination. This microscope has $8 \mathrm{x}$ to 40x magnification and an adjustable viewing distance of $55-75 \mathrm{~mm}$. Documenting the orientation and distribution of these striations and polishes over the surface of the bone tools is essential to determine whether they were used in a back-and-forth or rotary motion. The final step of the analysis involved drawing and photographing the bone tools ${ }^{10}$.

\section{TOOL TYPES AND FUNCTION}

Among the 263 bone tools excavated at Gülpınar, 38 diagnostic specimens are introduced here to provide a clear picture of the assemblage. The bone tools are divided into five groups based on the working edges, namely 'point ended', 'round ended', 'bevel ended', 'spatulae', 'hafts', and 'flat ended'.

\begin{tabular}{|c|c|c|c|}
\hline Type & Phase II & Phase III & Total \\
\hline Point Ended & 29 & 55 & $84(32 \%)$ \\
\hline Round Ended & 4 & 9 & $13(5 \%)$ \\
\hline Bevel Ended & 28 & 58 & $86(32,7 \%)$ \\
\hline Spatulae & 21 & 27 & $48(18,2 \%)$ \\
\hline Haft & 11 & 14 & $25(9,5 \%)$ \\
\hline Flat Ended & 5 & 2 & $7(2,6 \%)$ \\
\hline Total & 98 & 165 & 263 \\
\hline
\end{tabular}

Figure 1. Point-ended tools on ulnae (1-2) and metapodials and ribs (3-8) / Ulna kemiğinden (1-2) ve metapodial ve kaburga kemiğinden (3-8) yapılmış nokta uçlu aletler (1-8).

\section{Point Ended}

The most prominent bone tool-type attested at Gülpınar is the point-ended one, comprising $32 \%$ of the total bone tool assemblage with 84 examples (Figs. 1-4). This category is characterized by a markedly tapering sharp tip, mainly at one end, which use-wear indicates to be the working end. Because tools with points at both ends are rarely preserved intact, it is difficult to estimate if the broken pieces originally belonged to this category. Point-ended tools were mainly made from a variety of the skeletal parts of cattle, deer, and sheep/goats such as metapodials, ribs, and ulnae. The selection of ulnae to make point-ended tools has been attested at Gülpınar (Fig. 1.1-2). When metapodials were selected, they were reduced first through splitting and then ground to the intended shape, tapering to a pointed tip at one end. The point-ended tool often preserves part of the original epiphysis usually at the distal end (Fig. 1. 3-4). It appears that the epiphysis was ground so that it either did not hurt the palm of its user or had an aesthetic appearance (Fig. 1. 5-8). Those point-ended tools made from split long bones have slender shafts that are either circular or elliptical in cross-section. The point-ended tools from Gülpınar could be designated as an awl ("Bız" in

10 Yavşan 2020. 


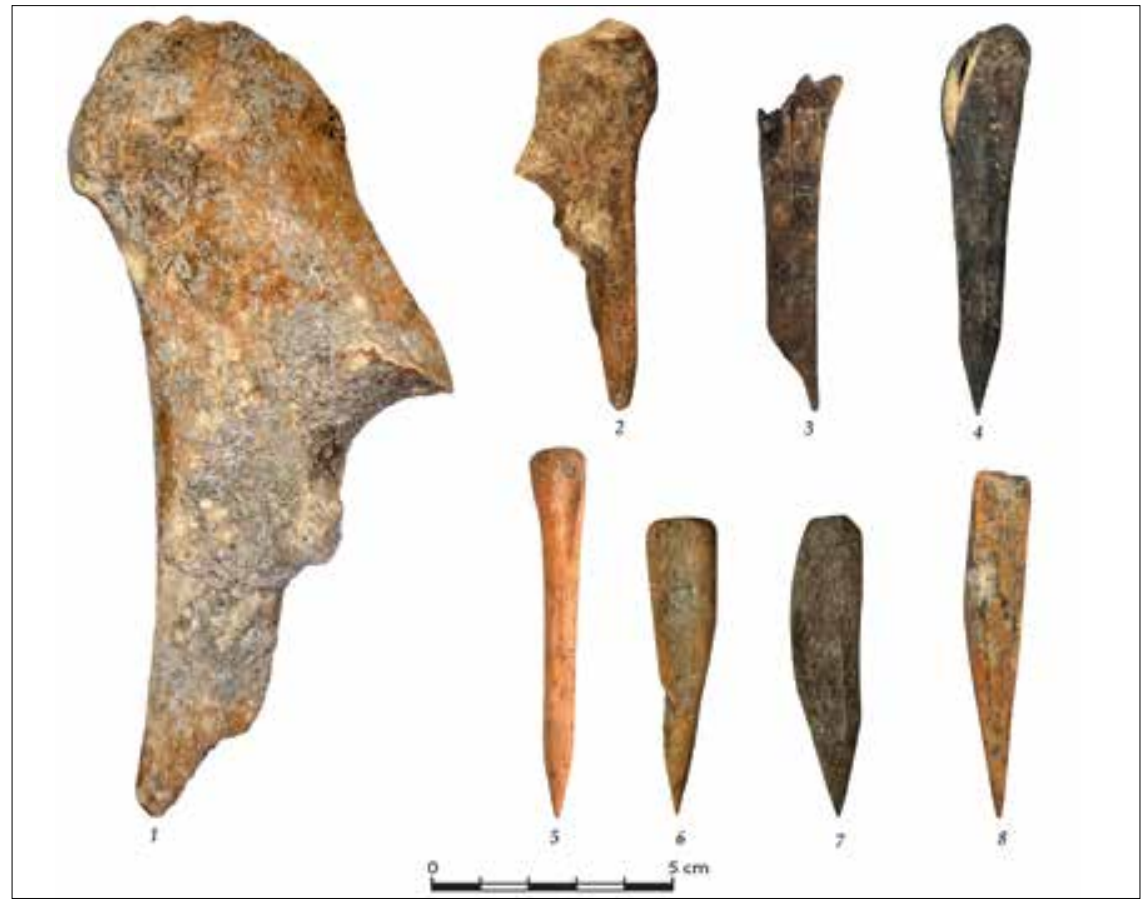

Figure 1. Point-ended tools on ulnae (1-2) and metapodials and ribs (3-8) / Ulna kemiğinden (1-2) ve metapodial ve kaburga kemiğinden (3-8) yapılmış nokta uçlu aletler (1-8).

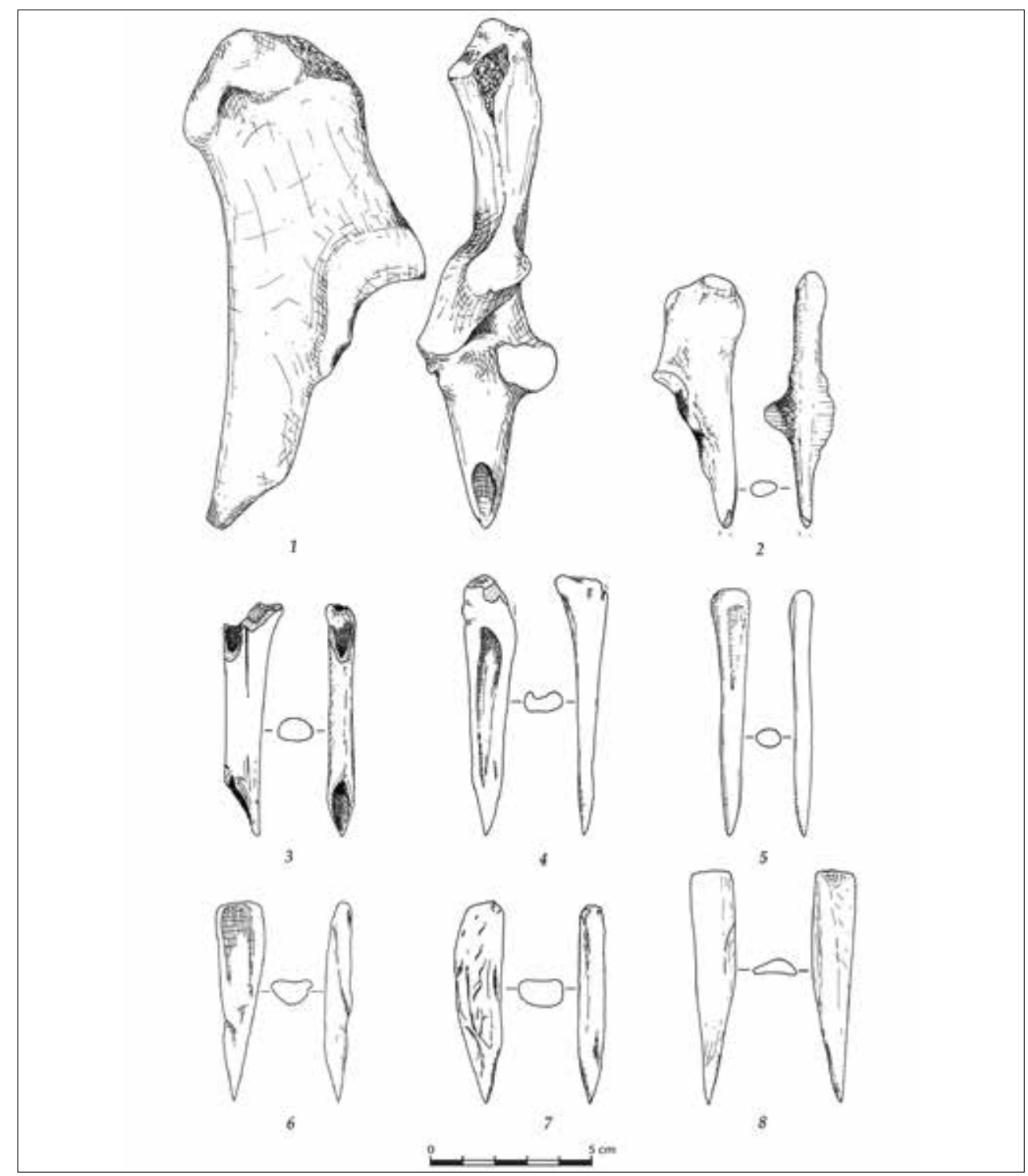

Figure 2. Point-ended tools on ulnae (1-2) and metapodials and ribs (3-8) / Ulna kemiğinden (1-2) ve metapodial ve kaburga kemiğinden (3-8) yapılmıs nokta uçlu aletler (1-8). 


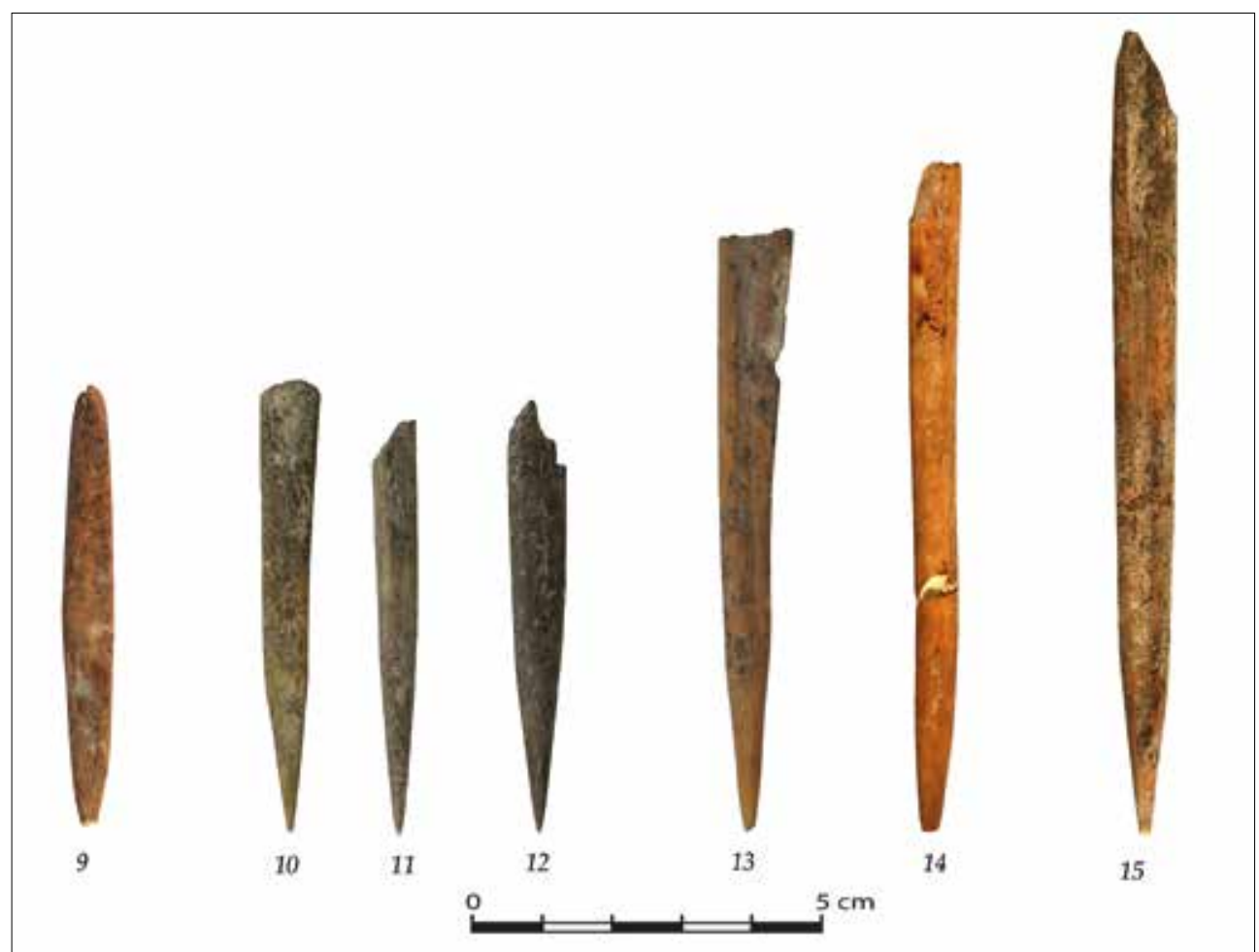

Figure 3. Tools pointed at both (9) and one end (9-15) / İki (9) ve bir tarafi (10-15) nokta uçlu aletler.

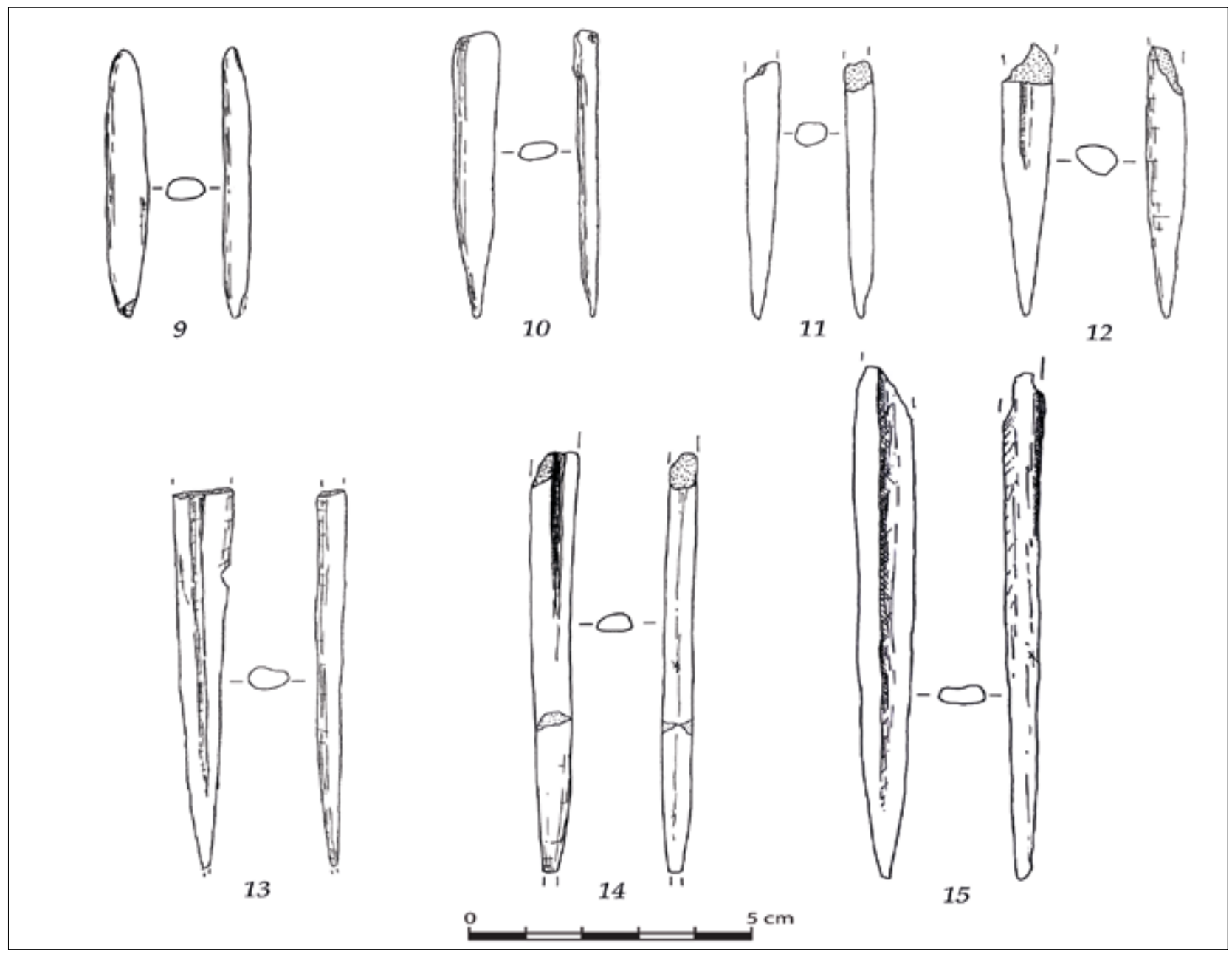

Figure 4. Tools pointed at both (9) and one end (9-15) / Iki (9) ve bir tarafi (10-15) nokta uçlu aletler. 


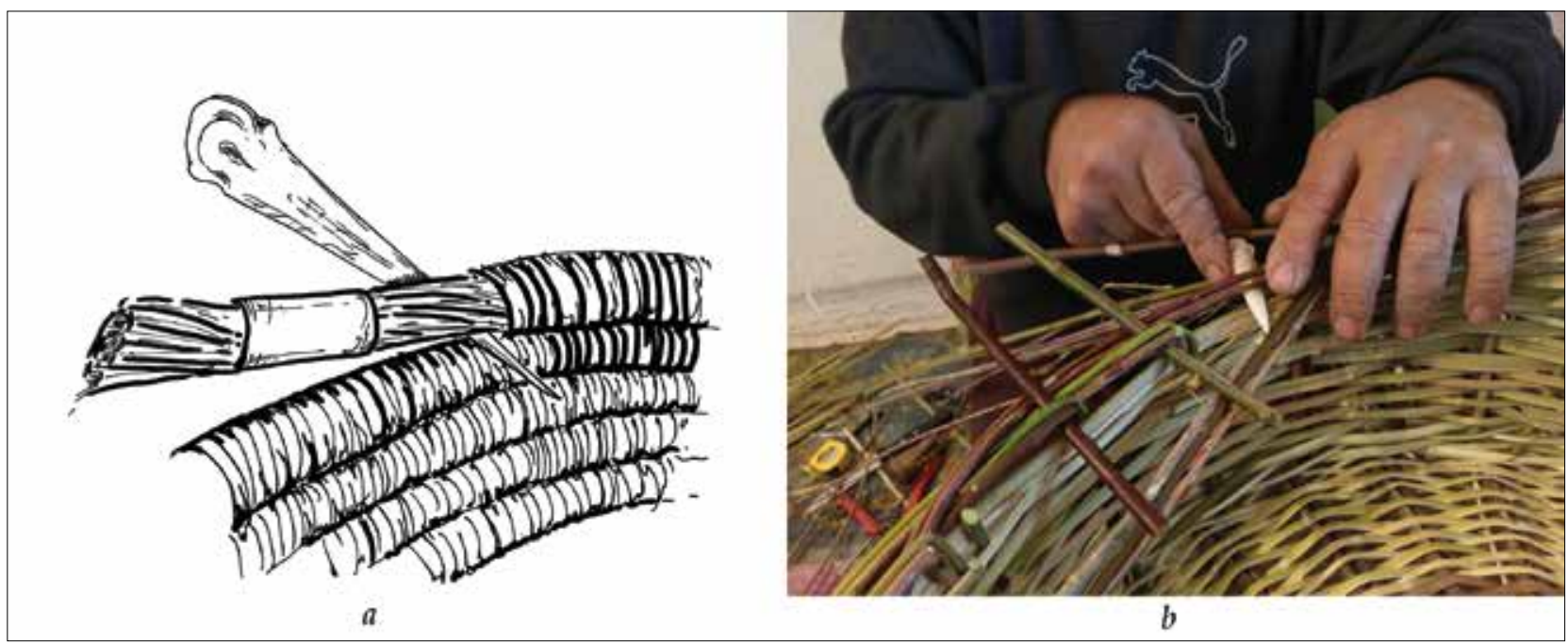

Figure 5. Tentative recontrusction of the use of a bone tool with pointed tip (awl) in basket making (a) and modern use of similar bone tool in coiled basketry in Çanakkale (b) / Nokta uçlu kemik aletin (bız) sepetçilikte kullanımı gösteren çizim (a) ve Çanakkale yöresinde benzer kemik aletin geçmişte sepetçilikte kullanımı (b)

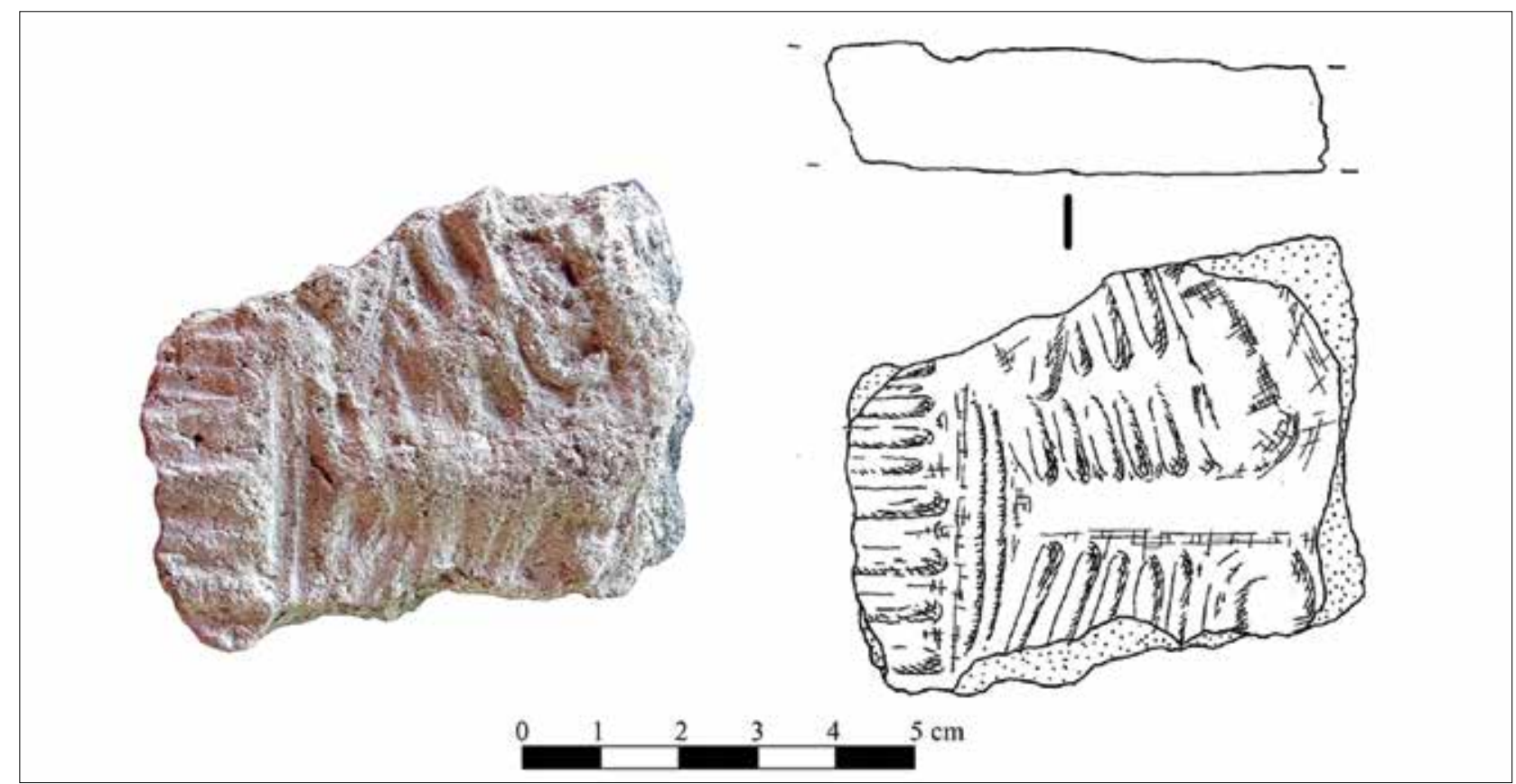

Figure 6. Fragment of a pot base with impressions of a basket from phase III at Gülpınar / Gülpınar Tabaka III buluntusu tabanında sepet negatif izi bulunan seramik kaidesi.

Turkish) and pin. Most point-ended tools appear to be broken in the middle of the shaft. No single evidence for a perforated point-ended tool that could be labeled as a needle was identified at Gülpınar.

The point-ended bone tools could have been used to carry out certain kinds of tasks at Gülpınar. Such tools with sharp tips were suitable in coiled basketry, which requires the piercing and sewing together of reeds and bundles of grass. ${ }^{11}$ Weaving, basketry, and mat making were common crafts during both phases as demonstrated by their negative impressions appearing on over 1200

11 Russell 1990: 528. pot bases. ${ }^{12}$ Although ethnographic evidence regarding the use of bone tools in Anatolia is very sketchy, there is patchy evidence from the town of Biga in northwestern Anatolia attesting to the use of awls particularly in making coiled baskets (Figs. 5-6). Here, interviews held with the last basket makers showed that bone awls were frequently used in the past before they were placed with the metal ones. The archaeological examples of pointended tools preserving striations parallel or diagonal to the longitudinal axis from both phases at Gülpınar could well be linked to coiled basketry, the presence of which was also confirmed on the negative impressions on pot bases.

12 Takaoğlu and Özdemir 2018: 485, fig. 49.10. 


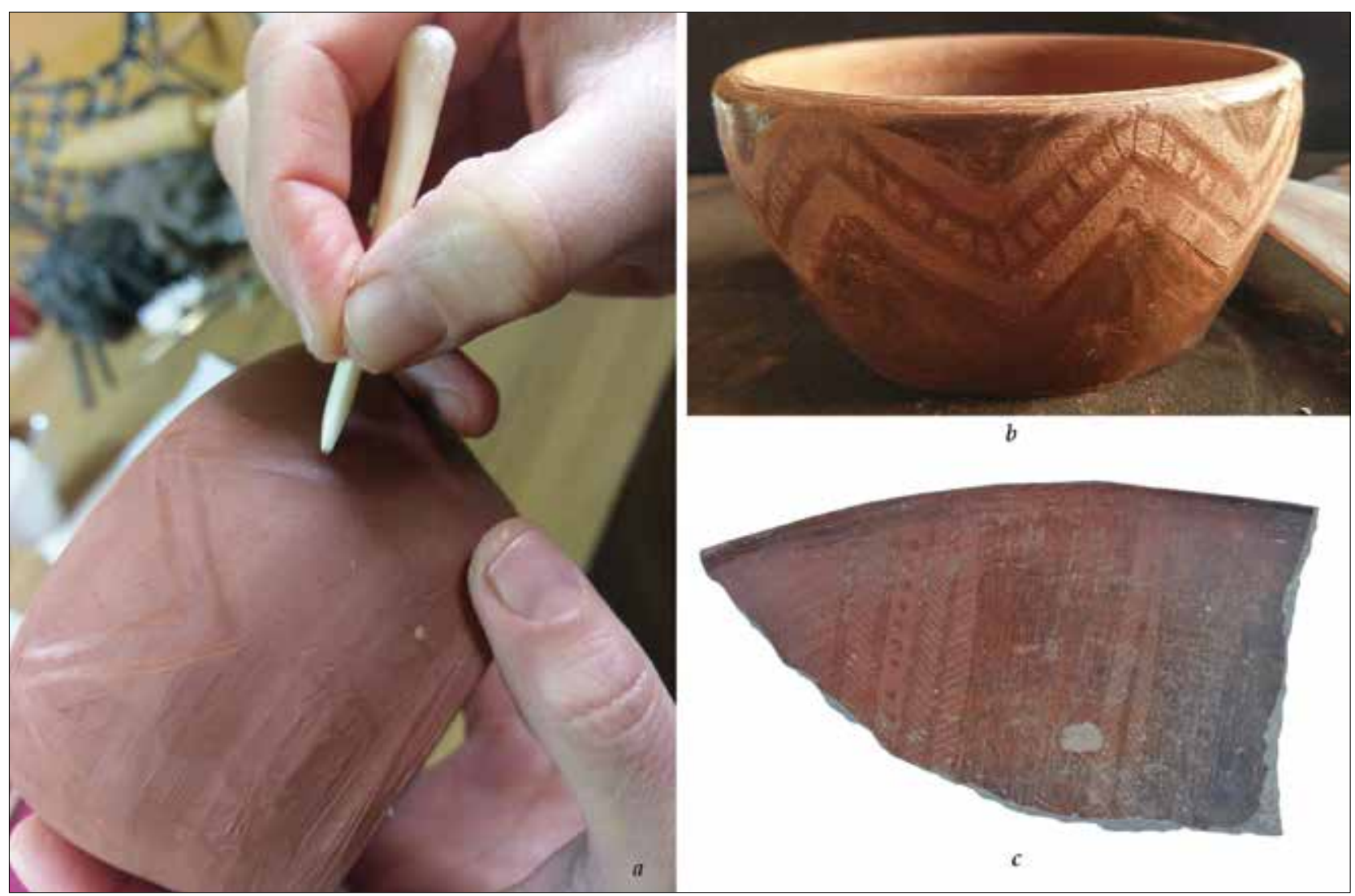

Figure 7. Experimental use of a point-ended bone tool in pattern-burnish decoration (a-b) and a rim fragment of a bowl with pattern-burnish decorated interior from Gülpınar (c) / Nokta uçlu kemik aletin perdah bezeme yapımında kullanımı (a-b) ve Gülpınar kazılarından içi perdah bezeme dekorlu bir seramik parçası (c).

Certain point-ended tools preserve a high polish and faint horizontal striations at their tips. These tools could have been used for the preparation of animal skins or for making stitching holes before the sewing process in the preparation of clothes and shoes. Replication studies conducted on the methods of piercing hides using point-ended bone tools elsewhere provided useful results, demonstrating that bone tools with pointed ends are used for punching holes in fresh and dried hides when stretched on a wooden surface. ${ }^{13}$ The possibility that this type of point-ended tool might have been used in the form of a pin to fasten hair or garments can also be taken into consideration.

There is ample ethnographic and ethnohistoric evidence among the North American natives attesting to the three different common uses of bone awls, namely coiled basketry, tule reed mat making, and hide working. ${ }^{14}$ The ethnographic and ethnohistoric evidence leads us to surmise that certain bone awls were often used to pierce a hole through strips in coiled basketry. In the making of tule reed mats, on the other hand, a long bone point-ended tool is pushed through the reeds, meaning that smaller tools such as awls may not be necessary. The evidence also points to the use of awl-like point-ended bone tools made mainly from metapodials and ribs in the making of

13 Christidou and Legrand 2005.

14 Chomko 1975; Olsen 1979: 353-357; Tanner 1982: 18; Kaddie 2012a; Mason 2012: 85. clothing, shoes, and bags from animal hides. According to the same North American evidence, point-ended tools made from ulnae with minimal modifications were mainly used in tasks such as manipulating fibers in making baskets and mats, as well as tying of spear points using animal sinew. ${ }^{15}$ It is also argued that the initial piercing of the hide was achieved first with an awl with sharp tips operated in a rotary motion and this was followed by the enlargement of this piercing with rather large round-ended tools made of antler are employed in a back-and-forth motion. Large ulna points could also well fit within this task.

At Gülpınar, certain point-ended tools may have been employed by potters, who used them in creating patternburnish or incision decorations in pot making. Nearly 300 fragments of potsherds bearing pattern-burnish decoration indicate that point-ended tools were preferred by the potters in forming decorative patterns when the pots were still dry before firing. The pattern-burnished decoration was achieved by the potter rubbing a pointed implement back and forth over the surface of the pots before they were fired. When the pots are fired, dark patterns are discerned from the unburnished parts of the surface, which is lighter in appearance. Experimental studies conducted by the present author show that pointended bone tools were also used in creating patternburnished decorations (Fig. 7).

15 Kaddie 2012b; James 2014: 77, figs. 84-85. 


$$
18191
$$




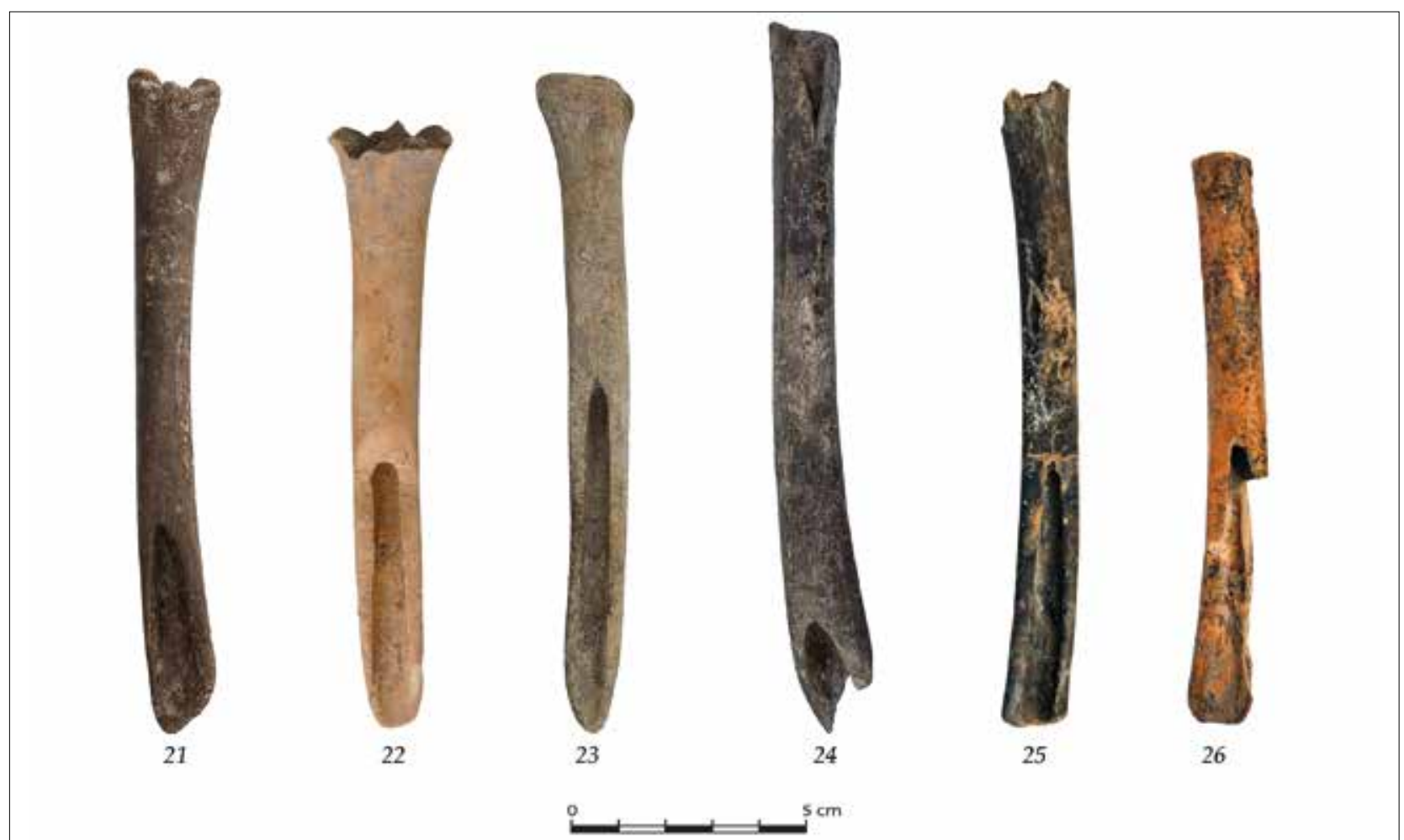

Figure 10. Bevel-ended tools from metapodials of animals (21-26) / Hayvanların uzun kemiklerinden yapılmış eğimli uçlu aletler (21-26) Figure 10. Bevel-ended tools from metapodials of animals (21-26) / Hayvanların uzun kemiklerinden yapılmış eğimli uçlu aletler (21-26)

\section{Round Ended}

Round-ended tools are represented by 13 examples at Gülpınar, comprising only $5 \%$ of the bone tool assemblage. This category of tools, with a somewhat blunt tip instead of a sharp point, is made from long bones and horns of cattle, as well as antler tines of deer species (Figs. 8-9). These round-ended bone tools made from deer antlers derived from both common fallow deer (Dama dama) and red deer (Cervus elaphus). The antlers were seemingly collected from nearby once forested areas after they had been shed by the deer, although there is evidence that they were also obtained from hunted deer. There are cut marks on these antler tines from Gülpınar showing how they were detached from a rack employing the "cut and break" method. The fact that some of the deer craniums preserve the pedicles, and part of the faunal data representing wild animals includes the skeletal parts of deer, indicates that the toolmakers might not have also depended on naturally shed antlers at Gülpınar. Because the antler tine has naturally rounded tips, it was not always deemed necessary to modify them. Several examples, however, preserve actual traces of sharpening at their tips on both angles, making them discernible from the unmodified antler tines. This is because it is commonly accepted that the wear or polish observed at the tip of the antlers is derived from the deer rubbing its rack on a tree as it prepares for the shedding of its antlers. ${ }^{16}$ Although the function of tools made from

$\overline{16}$ Russel 1990: 540. antler tines is uncertain, horizontal striations observed on their tips under a stereo microscope imply that they were used as some sort of perforator. This could be linked to tasks such as piercing holes during hide preparation. Such round-ended tools made from antler tines could also have been used as digging tools to gather wild roots or for planting seeds.

\section{Bevel Ended}

Another common bone tool-type attested at Gülpınar is bevel-ended tools, comprising $32,7 \%$ of the total bone tool assemblage, with 86 examples. Bevel-ended tools exhibit a working edge in the shape of an angled crosscut made by breaking the distal end off at an angle and then grinding the exposed edge from one side, although several examples have beveled ends on both sides (Figs. 10-11). One end often preserves part of the original epiphysis. Such bone tools were commonly made from long bones such as the tibia, humerus, femur from cattle, deer, and sheep/goats.

Several hypotheses can be offered for the function of this type of bone tool with beveled ends. This category of bone tools probably had a range of uses, serving multiple purposes such as smoothing, scraping, and gouging. The most frequently appearing type of bevel-ended tools, illustrated in Figures 10 and 11 ("Mablak" in Turkish), has often been linked with tasks in hide processing. The beveled working 


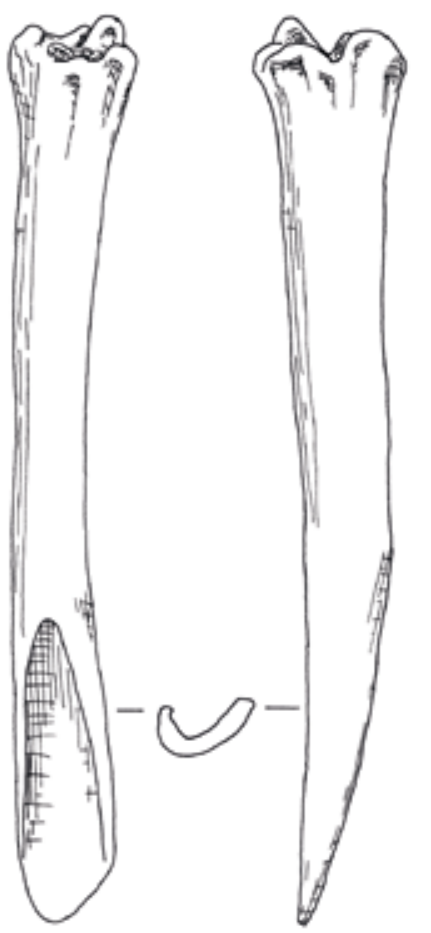

21

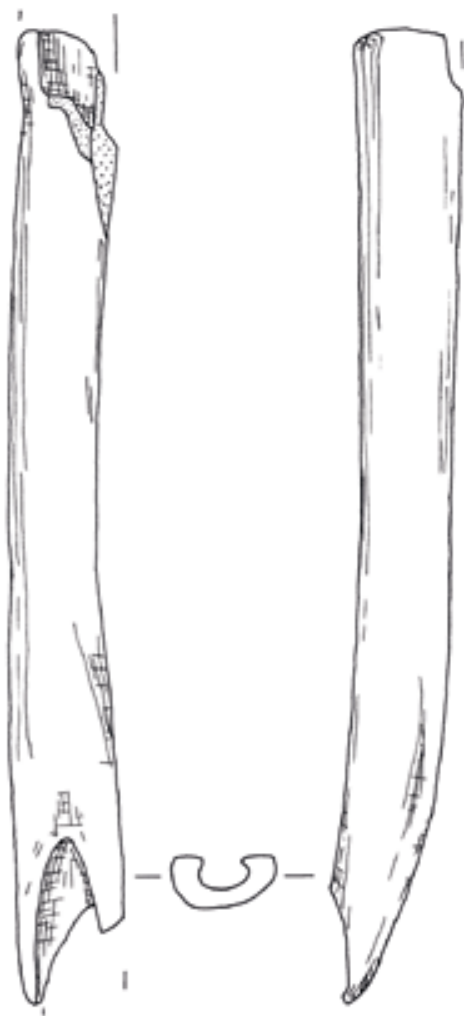

24

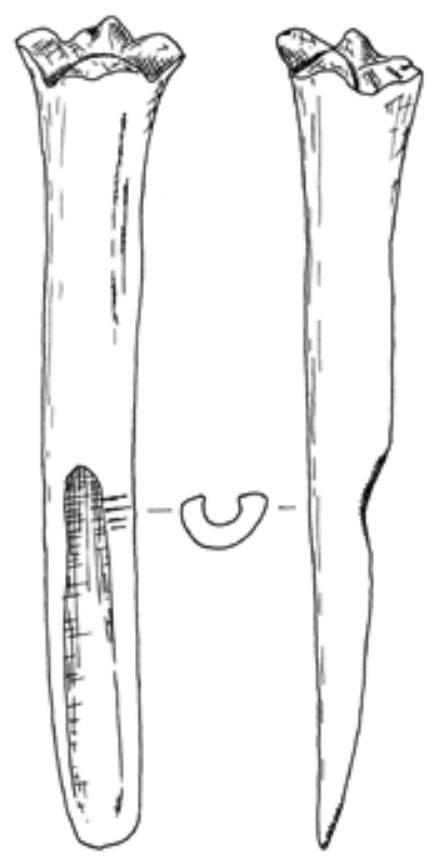

22

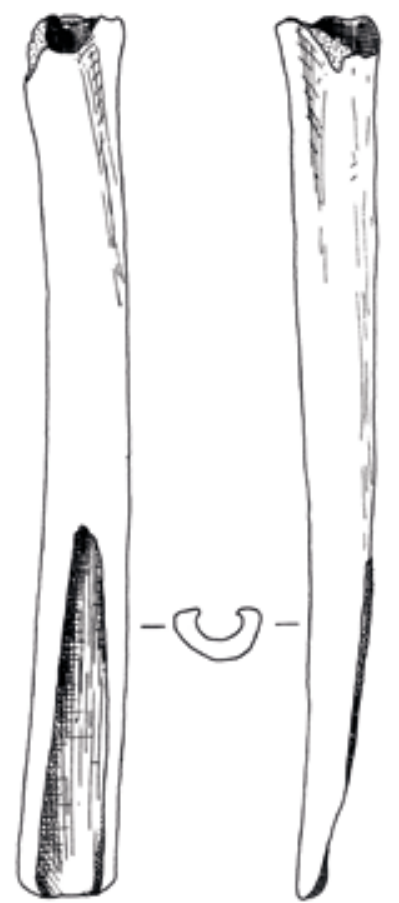

25

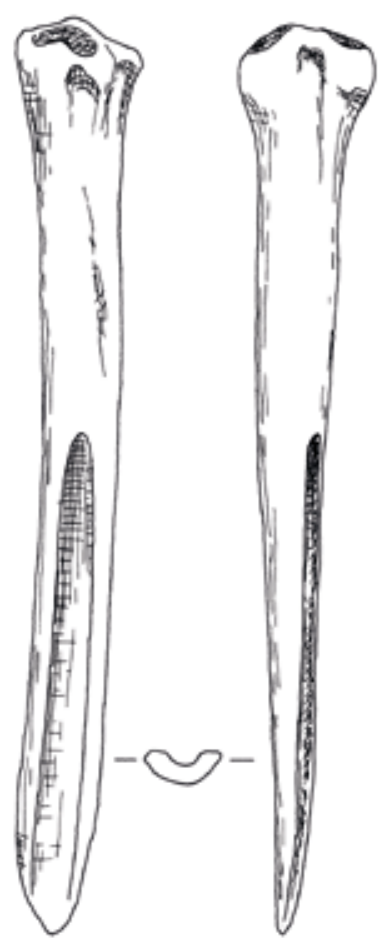

23

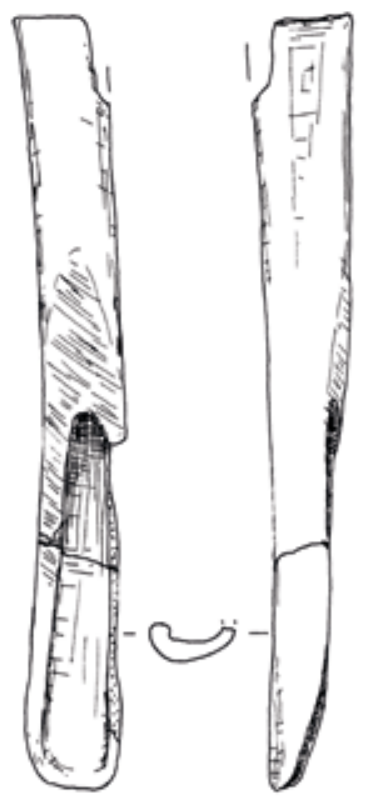

26

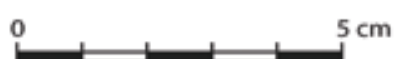

Figure 11. Bevel-ended tools from metapodials of animals (21-26) / Hayvanların uzun kemiklerinden yapılmış eğimli uçlu aletler (21-26) 


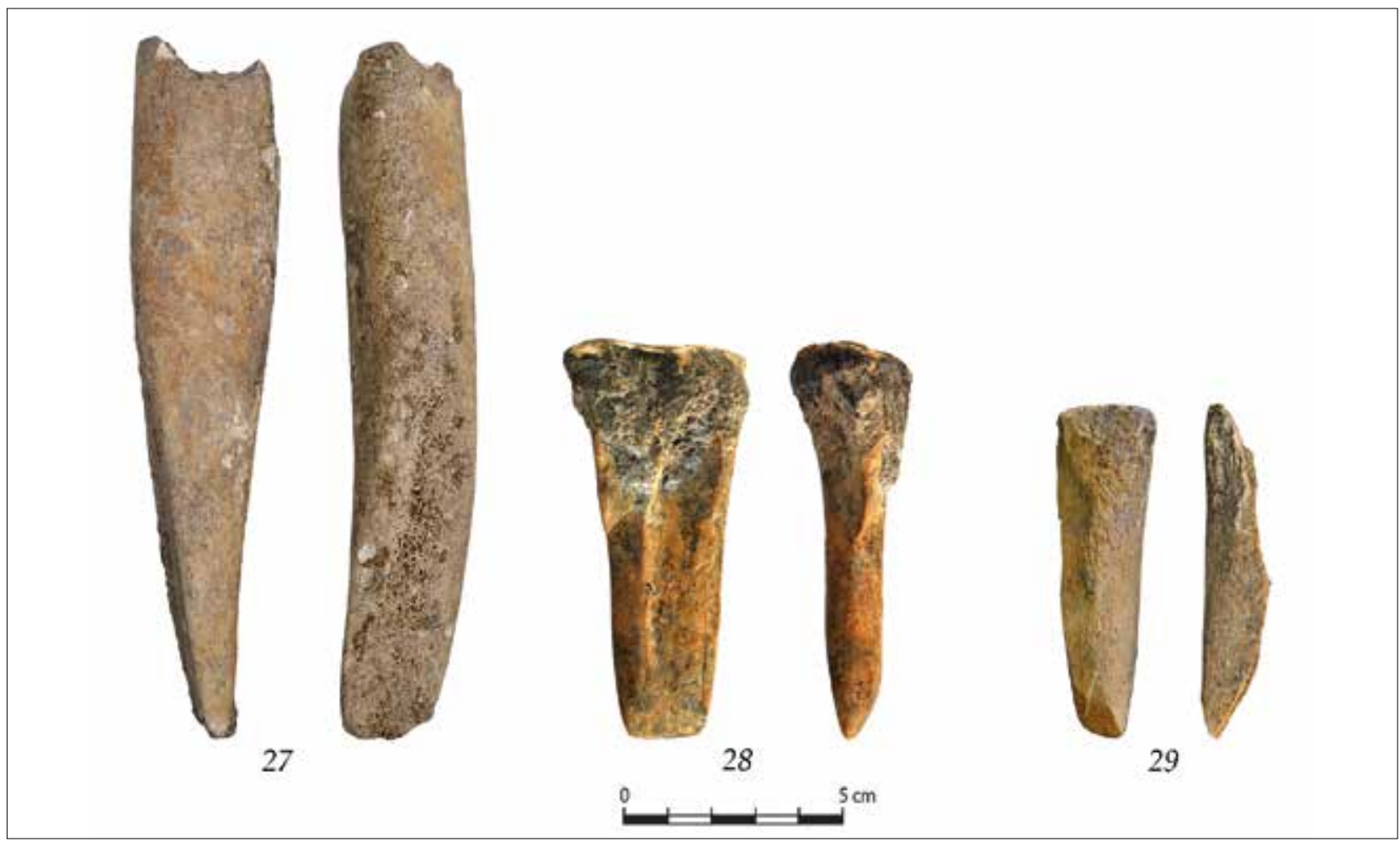

Figure 12. Bevel-ended bone tools (27-29) / Eğimli uçlu kemik aletler (27-29)

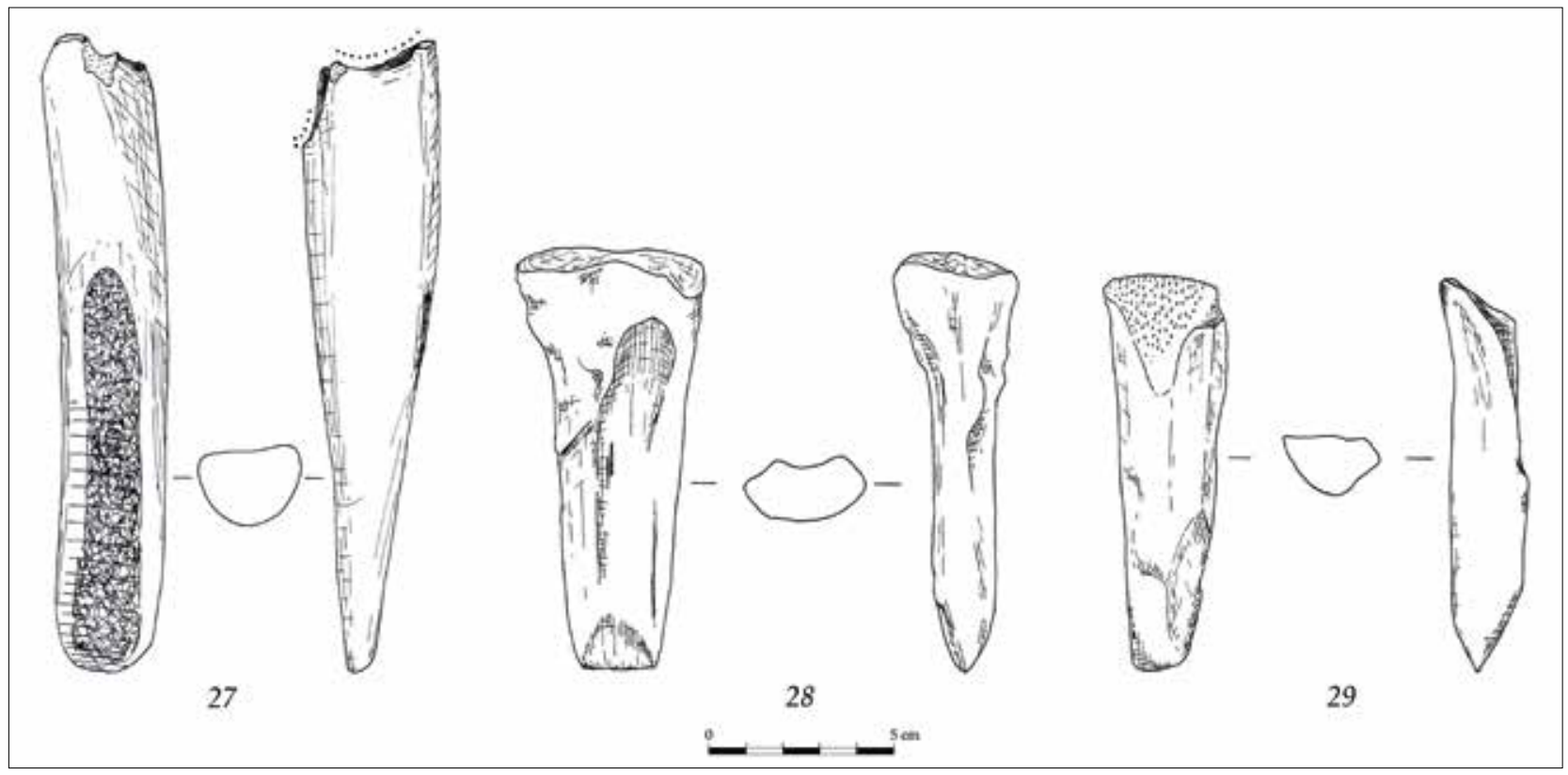

Figure 13. Bevel-ended bone tools (27-29) / Eğimli uçlu kemik aletler (27-29)

edge of the tool is rubbed over the hide to make it tougher and impermeable before it is transformed into a garment or a kind of footwear. This type of tool may also have been used in tasks such as smoothing pottery, scraping the flour from grinding stones, or mixing pigments or spices. There is also a group of bevel-ended tools made out of the scapula of cattle. Such large tools could be classified as hoes used in loosening the earth before planting a field. Hoes were also made from long bones of animals (Fig. 12.27). A small group of bone tools beveled on both sides has also been documented among the bevel-ended tool category (e.g. Figs. 12.28-29). 


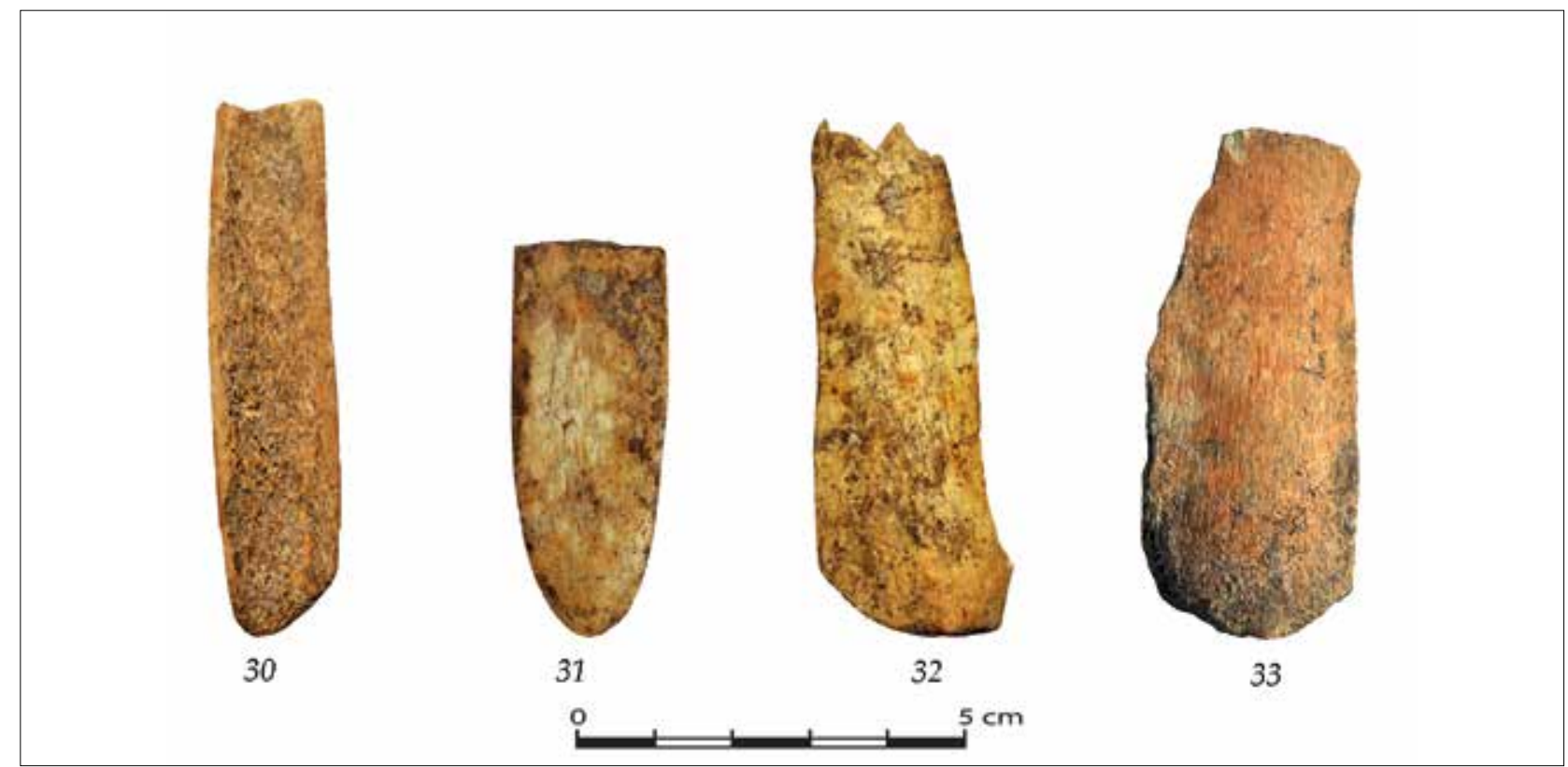

Figure 14. Spatulae (30-33) / Spatulalar (30-33)

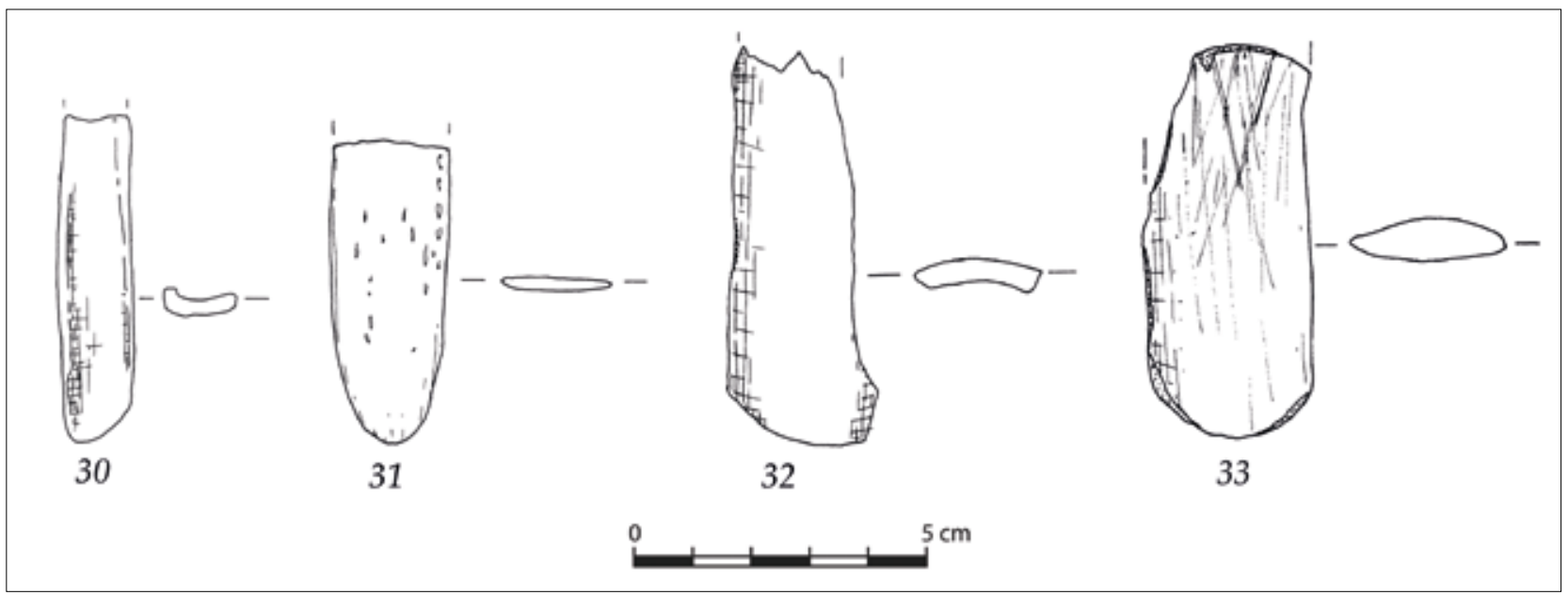

Figure 15. Spatulae (30-33) / Spatulalar (30-33)

\section{Spatulae}

Spatulae bone tools are also common among the bone tool assemblages of both phases at Gülpınar. They are mainly made from the ribs cattle and sheep/goats with little modification (Fig. 6). A spatula, which has a flat shaft generally made from ribs split lengthwise, usually display a large and flat end. They are basically tools that could have been used for a wide variety of tasks that could easily be linked with the steps of pottery manufacture, such as the shaping, smoothing, and decoration of pots. Experimental studies conducted by the present author and the ethnographic evidence from Anatolia both confirm that such bone tools were very efficient in the several steps of pot making.

\section{Hafts}

Hafts made of deer antlers, as well as the horns of cattle and both wild and domesticated sheep and goats, have also been identified at Gülpınar. These hafts were frequently made from horns of cattle and sheep/goats, as well as antlers from common fallow deer (Dama dama). There are also rare cases in which long bones of cattle were also preferred to manufacture hafts (Figs. 16-17). In manufacturing the hafts, the spongy inner material at one end of the selected section of the horn or antler was partially hollowed out to insert a stone tool in it. It seems that most hafts unearthed at Gülpinar were mainly manufactured to accommodate stone chisels. The recovery of an antler haft along with a miniature greenstone ax confirms this hypothesis. This haft, with a miniature stone chisel inserted into it, was found along with a group of finished bone tools around 


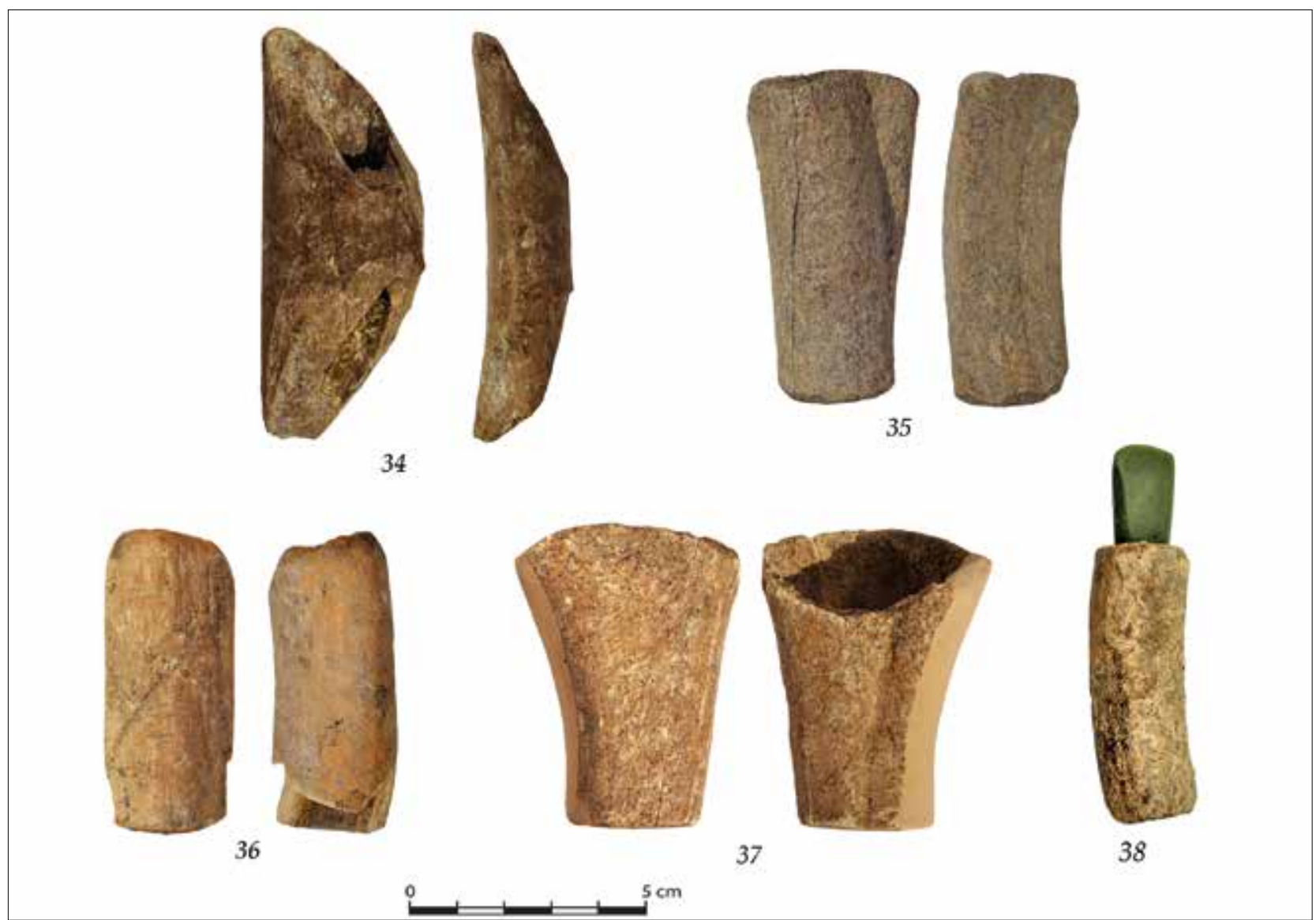

Figure 16. Bone (34) and antler hafts (35-38) / Kemik (34) ve boynuz saplar (35-38).

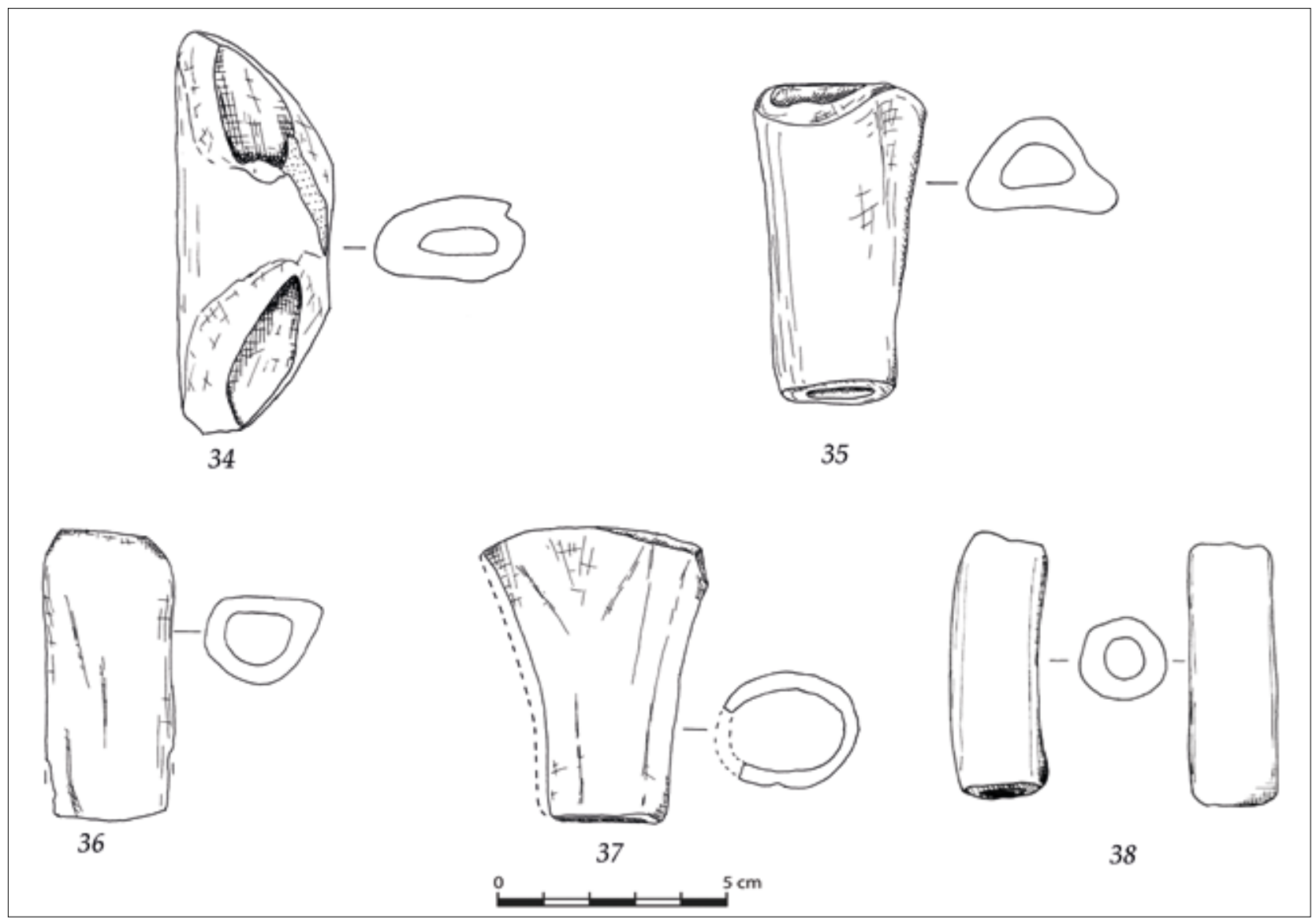

Figure 16. Bone (34) and antler hafts (35-38) / Kemik (34) ve boynuz saplar (35-38). 
a batch of grinding slabs near the southwestern corner of Room 36 of Building L, belonging to phase III. This part of the room was probably set apart for household craft production. The lack of evidence such as waste byproducts related to bone tool production indicates that this area was a locus where already finished bone tools were used in certain household craft production activities.

\section{CONCLUDING REMARKS}

At Gülpınar, bone tools clearly constituted an important component of the household craft activities. Because bone was readily available raw material for the fabrication of tools, the residents of the site took advantage of the bones leftover from the meals and shed antlers they found around their settlers to make tools for their daily needs. The lack of morphological standardization in all available bone tool types and low level in the intensity and scale of production enable us to view the example of bone tool production at Gülpınar as a specialized craft activity. Instead, bone working at Gülpınar could have been a domestic activity geared towards fulfilling the tools needs of individuals responsible for crafts such as mat and basket making, hide working, and pot making. The skills related to the manufacture of bone tools may have been transferred from generation to generation during the site's occupation. One behavioral trait of toolmakers that can be deduced from examination of the taxa from tools, however, is the preference for certain skeletal parts of animals for specific tool types. The toolmakers depended on discarded bones from both wild and domestic animals. Skeletal parts such as tibiae, ulnae, humeri, ribs, as well as horns, and antlers were the main skeletal parts particularly selected for tool making. Although there is an increase in the number of bone tools from phase II to phase III at Gülpınar, the type of bone tool used during each phase remains the same. The spatial distribution of the bone tools within the site does not display any special pattern at Gülpınar since they were found either on the floors of dwellings or in their courtyards. There is only single case in which several finished bone tools were found in a cluster around grinding slabs identified on the floor of a building, perhaps attesting to a form of indoor craft activity during the phase II occupation.

It would be interesting to demonstrate the differences and similarities among the bone assemblages of western Anatolian Chalcolithic sites; however, this is not the case. The assemblages of bone tools at most Chalcolithic western Anatolian sites are relatively poor and consist of similar tool categories. The neighboring site of Kumtepe produced only single evidence of a bone tool dating to this period. ${ }^{17}$ The Middle Chalcolithic occupations at ÇineTepecik, Ulucak, Yeşilova, and Uğurlu yielded bone tool assemblages that bear elements comparable to those of Gülpınar. ${ }^{18}$ Unfortunately, no bone tools were reported

\footnotetext{
17 Sperling 1976: 323, no. 141.

18 Günel 2011: figs. 9.1-3 and 10.1-2; Caymaz 2013: figs. 22-23;
}

from other important excavated Middle Chalcolithic western Anatolian sites such as Liman Tepe, Kulaksızlar, Malkayası Cave, and Tavabaşı Cave. As at Gülpınar, the Middle Chalcolithic tool types represent more-or-less a continuation of the preceding Early Chalcolithic tradition at Uğurlu. ${ }^{19}$ Here one must also move with the premise that the morphological similarities among the bone tool types recovered from different Chalcolithic sites may not always mean that they were used in the same tasks in each settlement. The Gülpınar data allow us to establish the degree of similarities and differences among the cultural assemblages of the sites of this period in terms of bone tool use.

Because the Neolithic settlement was not excavated at Gülpınar, it is not possible to demonstrate the variations in the patterns of bone tool use between the Neolithic and Chalcolithic periods. Nevertheless, the detailed studies of bone tools from the sites of Ulucak and Uğurlu allow us to make some comments on this issue. The Neolithic phases at Uğurlu have several tool types that do not continue to be utilized during the succeeding Chalcolithic phases. The number of tools such as fishhooks and spoons, as well as certain needle sub-types such as the incision decorated ones seriously declined during the Early Chalcolithic phase III occupation at Uğurlu. The finds from Uğurlu and Ulucak in this sense demonstrates that there was both change and continuity in the types of bone tools from the Neolithic to the Chalcolithic period. Because the publications dealing specifically with the Chalcolithic bone artifacts are very few, the bone tool assemblage at Gülpınar, which represents the largest collection of bone tools found so far in any excavated Chalcolithic settlement in western Anatolia, shed some light on the ways how the bone tools were used in household production activities during this period.

\section{ACKNOWLEDGEMENTS}

I would like to thank Coşkun Özgünel, former director of the Smintheion (Gülpınar) excavations, who allowed me to participate in the prehistoric excavations. I would also like to express my gratitude to Turan Takaoğlu, the excavator of the prehistoric settlement of Gülpınar at Smintheion. This work is derived in part from a Ph.D. dissertation completed in the Department of Archaeology at Çanakkale Onsekiz Mart University. I am most grateful to the Scientific Research Projects division of the Çanakkale Onsekiz Mart University for their financial support (BAP Projesi Kodu: SDK-2015605). I am also thankful to American Research Institute in Turkey (ARIT) for granting me the WDE Coulson \& Toni Cross Aegean Exchange Program to work on the material during the early stage of writing my dissertation.

Paul and Erdoğu 2017: 366

19 Paul and Erdoğu 2017: 366-77. 


\section{REFERENCES}

AZERİ, H. 2015.

"Aşağı Pınar Höyüğü Kalkolitik Dönem Kemik Buluntularının Değerlendirilmesi”, İstanbul Üniversitesi Sosyal Bilimler Enstitüsü, Yayınlanmamış Yüksek Lisans Tezi.

BULUT, H. 2014.

"Batı Toros Mağaraları Kemik Aletleri”, Ankara Üniversitesi Sosyal Bilimler Enstitüsü, Yayınlanmamış Yüksek Lisans Tezi.

BULUT, H. 2016.

"Karain Mă̆arası örnekleri ışı̆̆ında bark extractor (Ă̆aç kabuğu soyucu): Yeni bir öneri”, Adalya 19: 1-16.

BULUT, H. 2018.

“Prehistorik Dönemlerde Anadolu'da Kemik Alet Endüstrisi: Bölgesel Sentezler ve Karşılaştırmalı Değerlendirmeler", Ankara Üniversitesi Sosyal Bilimler Enstitüsü, Yayınlanmamış Doktora Tezi.

CAYMAZ, T. 2013.

"Yeni veriler ışı̆̆ında Orta Batı Anadolu Kalkolitik Çağ kültürü”, Arkeoloji Dergisi 18: 39-112.

CHOMKO, S.A. 1975

"Bone awls and utilized antler tines from Arnold Research Cave, 23CY64, Missouri." Plains. Anthropologist 67: 27-40.

CHRISTODOU, R. / A. LEGRAND, 2005

"Hide working and bone tools: Experientation Design and Apllications.", From Hooves to Horns, from Mollusc to Mamoth. Manufacture and Use of Bone Artifacts from Prehistoric Times to the Present, H. Luik, A.M. Choyke, C. Batey, L. Lougas, eds., Muinasajaj teadus 15, 385-396.

ÇEVIK, Ö. 2018.

"What follows the Late Neolithic occupation in centralwestern Anatolia? A view from Ulucak", Communities in Transition: The Circum-Aegean Later Neolithic Stage (ca. 5000/4800-3200/3000 BC), eds. S. Dietz, F. Mavridis, Z. Tankosic and T. Takaoğlu. Oxford, 506-512.

DEKKER, K. 2014.

"What Tools Can Tell. The Bone Tools of Barçın Höyük", Unpublished MA thesis, Free University of Amsterdam

DERIN, Z. / T. CAYMAZ. 2018.

"The Chalcolithic period at Yeşilova Höyük", Communities in Transition: The Circum-Aegean Later Neolithic Stage (ca. 5000/4800-3200/3000 BC), eds. S. Dietz, F. Mavridis, Z. Tankosic and T. Takaoğlu). Oxford, 499-505.
DERIN, Z. / M.A. ERDEM / Ö.Ç. MAMIKKOĞLU, 2020

“Yassıtepe Höyüğ̈̈”, İzmir Araştırmaları Dergisi 12: $61-74$

ELSTER, E.S. 2003

"Bone tools and other artifacts", Prehistoric Sitagroi: Excavations in Northeat Greece, 1968-1970, Volume 2: The Final Report, E.S. Elster and C. Renfrew, eds., Los Anageles: University of California (Cotsen Institute of Archaeology, Monumenta Archaeologica 20), 52-79.

ERDALKIRAN, B. 2017.

"Barçın Höyük 2015 yılı kemik aletlerinin ön raporu", Arkeometri Sonuçları Toplantısı 32: 235-249.

ERDOĞU, B. 2018.

"The Neolithic to Chalcolithic Transition the Island of Gökçeada (Imbros)", Communities in Transition: The Circum-Aegean Later Neolithic Stage (ca. 5000/4800-3200/3000 BC), eds. S. Dietz, F. Mavridis, Z. Tankosic and T. Takaoğlu. Oxford, 367-372.

GÜNEL, S. 2011.

"Çine-Tepecik kazıları ışığında bölgenin tarihöncesi kültürleri üzerine bir inceleme”, Karadeniz'den Fırat'a Bilgi Üretimleri: Önder Bilgiye Armağan Yazılar, A. Öztan ve Ș. Dönmez, eds, Ankara, 217232 .

GÜNEL, S. 2018.

"Prehistoric Culture in Çine-Tepecik Höyük and its contribution to the archaeology of the region", Communities in Transition: The Circum-Aegean Later Neolithic Stage (ca. 5000/4800-3200/3000 BC), eds. S. Dietz, F. Mavridis, Z. Tankosic and T. Takaoğlu). Oxford, 541-550.

JAMES, G. W. 2014

Indian Basketry, New York: Skyhorse Publishing.

KADDIE, G. 2012a

"Bone awls: Bridging or widening the gap between the archaeology and ethnology", The Midden 44.1: 10-12.

KADDIE, G. 2012b

"Ulna bone tools: Identiying their function", The Midden 44.3/4: 23-28.

MASON, O. T. 2012.

American Indian Basketry. New York: Dower Publications.

OLSEN, S. L. 1979.

"A Study of Bone Artifacts from Grasshopper Pueblo, AZ P:14:1", Kiva 44: 341-373. 
ÖZDEMIR, A. 2017.

"Prehistorik Gülpınar (Smintheion) Yerlesimi Mimarisi ve Mekansal Kullanımı.”, Çanakkale Onsekiz Mart Üniversitesi Sosyal Bilimler Enstitüsü, Yayınlanmamış Doktora Tezi.

PAUL, J.W. / B. ERDOĞU, 2017.

"An examination of the worked bone and antler assemblage at Uğurlu (Gökçeada, Turkey).", Documenta Praehistorica, 44: 368-385.

PIŞKIN, E. / TAKAOĞLU, T. 2020.

"Animal exploitation in the subsistence base of the Chalcolithic Gülpnar community.”, Türkiye Bilimler Akademisi Arkeoloji Dergisi, 27.

RUSSEL, N. 1990.

"The bone tools.", Selevac. A Neolithic Village in Yugoslavia, R. Tringham and D. Krstıć, eds., Los Angeles, Monumenta Archaeological 15, 521-548.

SAĞLAMTIMUR, H. / A. OZAN, 2012.

"Ege Gübre Neolitik Yerleşimi", Ege Üniversitesi Arkeolojik Kazılart, eds. A. Çilingiroğlu, Z. Mercangöz, G. Polat. İzmir, 223-241.

SivíL, C. 2017.

"Ulucak Höyük Neolitik Dönem Kemik Aletleri'nin Tabakalar ve Mekânlar Arası Değerlendirilmesi”, Trakya Üniversitesi Sosyal Bilimler Enstitüsü, Yayınlanmamış Yüksek Lisans Tezi.

TAKAOĞLU, T. (n.d.).

"Kulaksızlar Revisited: Excavations towards the context of a marble workshop", in The Archaeology Anatolia. Recent Discoveries (2019-2020), Vol. IV, eds. S. Steadman and G. McMahon. Cambridge.

TAKAOĞLU, T. / A. ÖZDEMIR, 2018.

"The Middle Chalcolithic period in the Troad: A new look from Gülpınar", Communities in Transition: The Circum-Aegean Later Neolithic Stage (ca. 5000/4800-3200/3000 BC), eds. S. Dietz, F. Mavridis, Z. Tankosic and T. Takaoğlu). Oxford, 479-490.

TANNER, C. L. 1982.

Apache Indian Baskets, Tucson: The University of Arizona Press.

TUNCEL, R. / V. SAHOĞLU. 2018.

"The Chalcolithic of Coastal Western Anatolia: A view from Liman Tepe, İzmir", Communities in Transition: The Circum-Aegean Later Neolithic Stage (ca. 5000/4800-3200/3000 BC), eds. S. Dietz, F. Mavridis, Z. Tankosic and T. Takaoğlu. Oxford, 513-529.
YAVŞAN, Ç. 2010.

"Kalkolitik Gülpınar (Smintheion) Kazıları Buluntusu Deniz Kabukları", Çanakkale Onsekiz Mart Üniversitesi Sosyal Bilimler Enstitüsü, Yayınlanmamış Yüksek Lisans Tezi.

YAVŞAN, Ç. 2020.

"Prehistorik Gülpınar (Smintheion) Kemik Aletleri: Üretim ve Kullanım Modelleri”, Çanakkale Onsekiz Mart Üniversitesi Sosyal Bilimler Enstitüsü, Yayınlanmamış Doktora Tezi. 
